\title{
Reproductive cycle of Aplodinotus grunniens females (Rafinesque, 1819) in the Usumacinta River, Mexico
}

\author{
Raúl E. Hernández-Gómez ${ }^{1}$, Wilfrido M. Contreras-Sánchez ${ }^{2}$, Arlette A. Hernández-Franyutti² \\ Martha A. Perera-García ${ }^{3}$ \& Aarón Torres-Martínez ${ }^{2}$ \\ ${ }^{1}$ División Académica Multidisciplinaria de los Ríos, Universidad Juárez Autónoma de Tabasco \\ Tabasco, México \\ ${ }^{2}$ División Académica de Ciencias Biológicas, Universidad Juárez Autónoma de Tabasco \\ Villahermosa-Cárdenas, Tabasco, México \\ ${ }^{3}$ División Académica de Ciencias Agropecuarias, Tabasco, México \\ Corresponding author: Wilfrido M. Contreras-Sánchez (contrerw@hotmail.com)
}

\begin{abstract}
The freshwater drum Aplodinotus grunniens is a species widely distributed in North America. In the Mexican southeast, this species occurs in the Usumacinta River, where it supports an artisanal fishery. In this regard, the present study was conducted to supply detailed information on the female reproductive cycle of this species. Calculations of gonadosomatic (GSI) and hepatosomatic (HSI) indexes, histological and visual staging of ovaries as well as the staging of oocyte development were applied together to determine the reproductive changes during an annual cycle. The histological analysis revealed the presence of spawning capable females throughout the year, and the distribution frequencies of oocyte diameters displayed the continuous occurrence of mature oocytes, with great data dispersion and different modal groups. These observations were further corroborated by the presence of alternating peaks and drops in the GSI and HSIs, which were correlated with the occurrence of maturing and spawned females. These data, taken together, reveal that A. grunniens from the Usumacinta River is a partial spawner with asynchronous ovarian development and undetermined fecundity that reproduces year-round, but with spawning occurring preferably during the rainfallflooding season (June to November). The Usumacinta River seems to be a permanently favorable environment for sheltering, feeding and growth of A. grunniens broods, especially during the flooding season. The information generated in this study will be useful for the development of management strategies in the wild as well as for the exploration of A. grunniens as a potential species for aquaculture production in southern Mexico.
\end{abstract}

Keywords: Aplodinotus grunniens; reproductive biology; histology; oogenesis; partial spawner; fecundity

\section{INTRODUCTION}

The freshwater drum Aplodinotus grunniens is the only species of the Aplodinotus genus that has permanently colonized freshwater environments (Nelson, 1994). The species is widely distributed in North America, from southern Canada, through USA and Mexico up to Guatemala, in Central America (Chao, 2002; Sluss \& Harrel, 2006). In spite of its wide distribution, only $A$. grunniens from northernmost populations inhabiting temperate zones have been subject of study, resulting in several studies about a range of topics such as diet, re- production, sexual dimorphism, growth, age and morphological variations among river ecosystems (Daiber, 1952; Rypel, et al., 2006; Rypel, 2007; DavisFoust et al., 2009; Jacquemin \& Pyron, 2013; Jacquemin et al., 2014).

Regarding reproduction, it was reported that $A$. grunniens occurring in various lakes located within USA and Canada, spawns between May and July, while in the Tennessee River the species spawns in September (Wallus \& Simon, 2006). Oocyte development was also described in A. grunniens specimens from the Red Lakes in Minnesota, USA, an area conside-

Corresponding editor: Enrique Dupré 
red as the northernmost limit in the range of distribution of the species (Palmer et al., 1995). By contrast, in populations inhabiting the tropical zone of its range, the reproductive biology of $A$. grunniens has been poorly investigated. In the case of A. grunniens population(s) occurring in the Usumacinta River, in the Mexican southeast, only two studies have been conducted until date; one focused on determining the potential of the species for aquaculture (Chávez et al., 1989) and another one that characterized the embryonic development using captive organisms (Hernández-Gómez et al., 2013). In the Mexican southeast, A. grunniens supports an artisanal fishery due to the quality and taste of its meat (NOM-037-PESC-2004). However, some studies have suggested that the abundance of several fish species in the Usumacinta River has been reduced in the last years, due to a generalized degradation of the Usumacinta basin caused by demographic expansion, environmental pollution and landscape modifications (Cabrera \& Cuc, 2002; Alvarez-Merino et al., 2014). This study was carried out to determine the developmental phases of female gonads throughout an annual cycle, using organisms inhabiting in the middle part of the Usumacinta River in Tabasco, southern Mexico, in view of the pivotal role that the understanding of reproduction plays for the development of fisheries management and fish conservation strategies (e.g., to establish catch and size limits as restrictions in the catch season).

\section{MATERIALS AND METHODS}

\section{Study area and fish sampling}

The study was carried out from January to December 2013. The sampling area was delimited from the Usumacinta River Canyon "Boca Del Cerro" $\left(17^{\circ} 25^{\prime} 33^{\prime \prime} \mathrm{N}, 91^{\circ} 29^{\prime} 29^{\prime \prime} \mathrm{W}\right)$ up to the locality of El Copo $\left(17^{\circ} 23^{\prime} 33^{\prime \prime} \mathrm{N}, 91.28^{\prime} 23^{\prime \prime} \mathrm{W}\right)$. This area was selected for the study because the abundance of the resource supports the only artisanal fishery for the species in the region. During low river levels (DecemberJune), specimens were captured using an $80 \mathrm{~m}$ long dragging net with $3 \mathrm{~m}$ height and $2 \mathrm{~cm}$ of net opening. During the flood months (July-November), on the other hand, captures were conducted using hooks, baited with freshwater shrimp (Procambarus llamasi). Eightyeight adult females were sampled, having an average weight of $452.4 \mathrm{~g}( \pm 198.75)$ and a total length (TL) of $33.52 \mathrm{~cm}( \pm 3.61)$. We aimed to sample 10 females per month; however, during June-October, when river depth increased, and sampling activities turned difficult, sample size varied from one to five specimens. Collected fish were sacrificed with an overdose of clove oil $\left(0.10 \mathrm{~mL} \mathrm{~L}^{-1}\right)$, and suffering was reduced as much as possible.

\section{Specimen processing}

For each female, the total length was measured using a conventional ichthyometer $( \pm 0.1 \mathrm{~cm})$. The total weight (TW) and gonadal weight (GW) were registered with a ScoutTMPro ${ }^{\mathrm{TM}}$ digital scale $( \pm 0.01 \mathrm{~g})$. The length and width of the ovaries were measured using a metric vernier caliper (the nearest $0.1 \mathrm{~mm}$ ). The gonadal volume $(\mathrm{GV})$ was estimated using the formula of an ellipsis $\mathrm{GV}=(4 / 3 \pi) \mathrm{a}^{2} \times \mathrm{b}$; where "a" is the diameter in the central portion of the gonad and " $b$ " is the length (Méndez-Marin et al., 2012). Sex was identified through macroscopic examination. For the histological processing, right ovaries were sampled by making three $3 \mathrm{~cm}$-thick cuts (anterior, middle and posterior) and quickly fixed in Bouin solution. The small ovaries were immersed $24 \mathrm{~h}$ and largest ones $48 \mathrm{~h}$. Afterwards, samples were washed in tap water to remove excess fixative. Samples were dehydrated in growing concentrations of ethanol (30, 50, 70, 96 and 99\%), cleared in xylene by $1 \mathrm{~h}$ (small gonads) or 1.5-2 $\mathrm{h}$ (large gonads), and finally embedded in paraffin (Paraplast). A series of $7 \mu \mathrm{m}$-thick cuts were obtained using a Reichert-Jung ${ }^{\mathrm{TM}}$ Model I sliding microtome. The selected sections were stained with hematoxylin-eosin, according to Humason (1979) and Aguilar et al. (2013).

\section{Microscopic analysis}

The histological analysis of Aplodinotus grunniens ovaries was carried out using a light microscope (Zeiss $^{\mathrm{TM}}$ Axiostar Plus model) coupled to a digital camera (Zeiss ${ }^{\mathrm{TM}}$ Axiocam MRc 5 model). Three histological slides from the middle portion of the ovary of each female were selected to determine the phases of gonad development. Gonads were classified as regenerating, developing, spawning capable, and regressing, according to the histological arrangement of somatic and germinal elements in the ovary. Also, the steps of oogenesis characteristic of each gonadal phase were described, and the diameters of the most frequent oocyte steps registered ( $\mathrm{n}=30$ in all cases). Only oocytes showing a germinal vesicle were measured. Measurements were done using the same Zeiss ${ }^{\mathrm{TM}}$ optic microscope linked to the AC AxioVision $\mathrm{r} 4.5$ program, designed to carry out morphometric measurements with an accuracy of $\pm 0.1 \mu \mathrm{m}$.

\section{Classification of the ovarian cycle and oogenesis}

The ovarian cycle of A. grunniens was classified in reproductive phases, according to Brown-Peterson et al. (2011) as immature (never spawned), regenerating, developing, spawning capable and regressing. Oocyte 
staging was performed following Grier et al. (2009), who classified oogenesis in stages and steps, as follows: 1) Oogonial proliferation (OP); 2) Chromatin nucleolus $(\mathrm{CN})$; 3) Primary growth (PG), further subdivided into the steps one nucleolus (PGon), multiple nucleoli (PGmn), perinucleolar (PGpn), oil droplets (PGod), and cortical alveoli (PGca); 4) Secondary growth (SG), further subdivided into early secondary growth (SGe), late secondary growth (SGl), and full grown oocytes (SGfg); 5) Oocyte maturation (OM), further subdivided into eccentric germinal vesicle (OMegv), germinal vesicle migration $(\mathrm{OMgvm})$ and germinal vesicle breakdown (OMgvb); and 6) Ovulation (OV). Although follicular atresia is not considered as part of oogenesis, this feature was also present in all the reproductive phases analyzed in this study and occurred in primary and secondary growth oocytes. In this study, the term phase was restricted to designate the reproductive condition of the ovaries during the annual cycle, and the term stage was restricted to describe the events of oogenesis that are common to all fish, that is, OP, PG, SG and OM. Finally, the term step was used to designate the sub-stages occurring during the main stages of oogenesis.

\section{Environmental conditions}

Data for river level, rainfall and water temperature were obtained from CONAGUA (Mexican National Water Commission) weather station number 30019 , located at the village of Boca Del Cerro, close to the study zone.

\section{Data analysis}

In order to determine the best indicators of the annual reproductive cycle of females, the gonadosomatic index (GSI) was calculated, with the equation: GSI $=\mathrm{Wg} / \mathrm{Wt}$ $\times 100$; where $\mathrm{Wg}$ : weight of the gonads $(\mathrm{g})$ and $\mathrm{Wt}$ : total weight of the specimen (g) (Rossendllum et al., 1987). The hepatosomatic index (HSI) was calculated with the equation: HSI $=\mathrm{Wh} / \mathrm{Wt} \times 100$; where $\mathrm{Wh}$ : weight of the liver $(\mathrm{g})$, and Wt: total weight of the specimen (g) (Rodríguez-Gutiérrez, 1992). All the statistical analyses were carried out with a confidence level of $95 \%$, using the Statgraphics Centurion ${ }^{\mathrm{TM}}$ v. 16 software.

\section{RESULTS}

The species presents paired elongated ovaries suspended from the dorsal body wall by the mesovarium (Fig. 1a). The ovaries communicate with the exterior through a common gonoduct, opening at the genital pore. Ovaries of Aplodinotus grunniens are cyst ovarian type; they have a central cavity toward eggs released after ovulation. From the inside out, the ovarian wall is made up of germinal epithelium, ovarian stroma, smooth muscle, connective tissue and a peritoneal epithelium. (Figs. 1b-e). Sampled females presented four of the five reproductive phases described by Brown-Peterson et al. (2011): regenerating, developing, spawning capable and regressing. The absence of young females in the immature phase may have resulted from a bias in the sampling method or the use of different ecosystems at this stage of development. Macroscopically, the ovaries ranged in texture and appearance from dough-like consistency in the regenerating phase, to granular and densely packed in the spawning capable phase. The reproductive phases observed were present throughout the year, indicating continuous reproduction. Bellow, we described the reproductive phases of A. grunniens females based on the gross morphology and histological characteristics of the gonads. The oocyte stages representative for each gonadal phase were also described.

\section{Regenerating}

This phase occurred more frequently during April and September (Fig. 2). It was observed in females with sizes between 29.03 and $36.56 \mathrm{~cm}$ (average $=31.82 \pm$ $2.44 \mathrm{~cm} \mathrm{TL}$ ), whose total weights ranged between 222.61 and $583.80 \mathrm{~g}(338.49 \pm 109.56 \mathrm{~g})$. The average GSI of females was $1.02 \pm 1.28$. In this phase, ovaries had an elongated shape, and they occupied approximately $1 / 3-1 / 2$ of the coelomic cavity. Ovaries were hardly vascularized with discreet blood capillaries. Their color ranged from cream to reddish, mainly towards the cephalic region (Fig. 3a). Oocytes in these ovaries were indistinguishable with the naked eye. The ovarian length varied from 34.96 to $70.20 \mathrm{~mm}(56.17 \pm$ $6.69 \mathrm{~mm})$ and total weight between 0.30 and $4.9 \mathrm{~g}(2.31$ $\pm 1.14 \mathrm{~g}$ ). Ovaries had an average volume of 1,333.62 $\pm 1,837.06 \mathrm{~mm}^{3}$. During this reproductive phase, ovaries contained primary growth oocytes including one nucleolus (PGon), multiple nucleoli (PGmn), perinucleolar (PGpn) and oil droplet (PGod) steps (Figs. 3b-i). The oocytes presented a densely basophile cytoplasm during the earlier steps, but they turned more acidophilic as development progressed. From all the oogenic steps identified, the multiple nucleoli (PGmn) was the most frequent $(42.7 \%)$, with a diameter ranging from 50 to $150 \mu \mathrm{m}$ (Fig. 3f).

\section{Developing}

This phase presented its highest frequency in August, October and November (Fig. 2), with females ranging from 29.13 to $40.45 \mathrm{~cm}$ TL $(35.51 \pm 3.07 \mathrm{~cm})$. Total weights varied between 232.71 and $997.82 \mathrm{~g} \mathrm{(572.20 \pm}$ $187.39 \mathrm{~g}$ ). The average GSI of females was $2.73 \pm 1.60$. Ovaries were larger than in the previous phase; they 

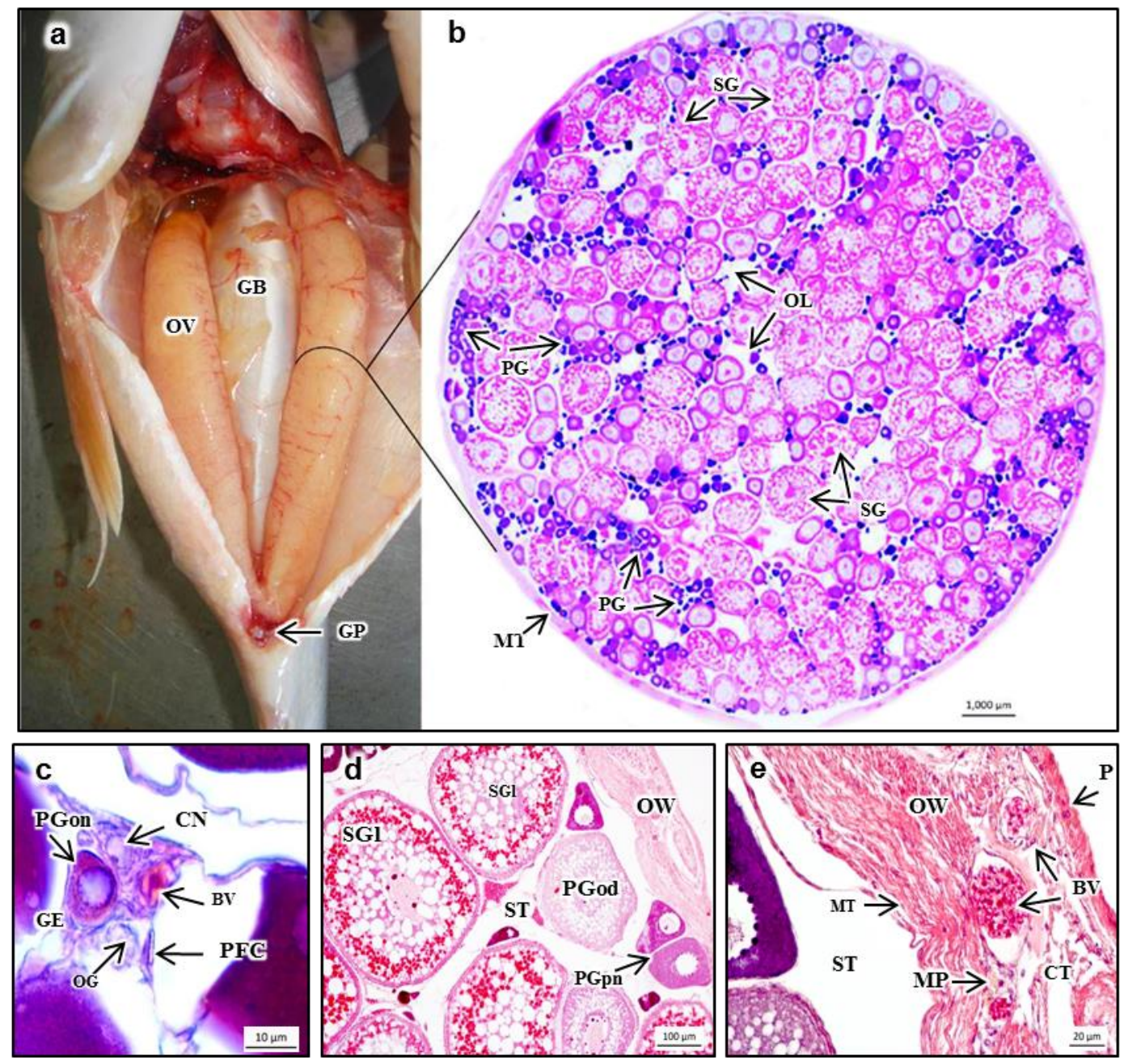

Figure 1. Gross morphology and anatomical location of Aplodinotus grunniens ovaries. a) The ovaries are paired organs located in the abdominal cavity. They communicate with the exterior through the genital pore (GP); b) histological cross section of a developing ovary showing a mass of oocytes in primary (PG) and secondary (SG) growth stages. The large number of oocytes has drastically reduced the ovarian lumen (OL). From the inside out, the ovaries consist of the following histological layers: the germinal epithelium, the ovarian stroma and the ovarian wall, described in $c, d$ and e images, respectively; c) the germinal epithelium (GE) is made of germ cells such as oogonia (OG), chromatin nucleolus (CN) and primary growth one nucleolus oocytes (PGon) as well as pre-follicular cells (PFC); d) the ovarian stroma (ST) consists of extracellular fluid and connective tissue, where follicles at different stages of development are immersed; e) the ovary is enclosed by the ovarian wall (OW), which consists of both muscular (MT) and connective tissue (CT), surrounded by an external epithelium, the peritoneum (P). Muscular tissue of the ovarian wall (MT), blood vessels (BV), primary growth perinucleolar oocyte (PGpn), primary growth oil droplet oocyte (PGod), late secondary growth oocyte (SGl), ovarian stroma (ST), melanomacrophage (MP). Hematoxylin and eosin stained.

were homogenous in shape but with a slight dilatation in the cephalic region, occupying around $2 / 3$ of the coelomic cavity. Vascular circulation was located ventrally, going across each ovary lengthwise (Fig. 4a). Oocytes were visible with the naked eye; they looked as granules ranging from milky to yellowish (Fig. 4a). Ovarian length during this phase varied from 47.55 to $100.66 \mathrm{~mm}(76.68 \pm 14.21 \mathrm{~mm})$, weighing between 5.60 and $32.90 \mathrm{~g}(16.19 \pm 7.45 \mathrm{~g})$, and with an average volume of $4,516.42 \pm 2,751.84 \mathrm{~mm}^{3}$. In this phase, oocytes in almost all the developmental stages/steps were observed, including primary growth oocytes such as multiple nucleoli (PGmn), Perinucleolar (PGpn), oil droplet (PGod) and cortical alveoli (PGca); and secondary growth oocytes in early secondary growth (SGe), late secondary growth (SGI) and full grown (SGfg) steps (Figs. 4b-e). The secondary growth stage of oogenesis was characterized by the gradual accumu- 


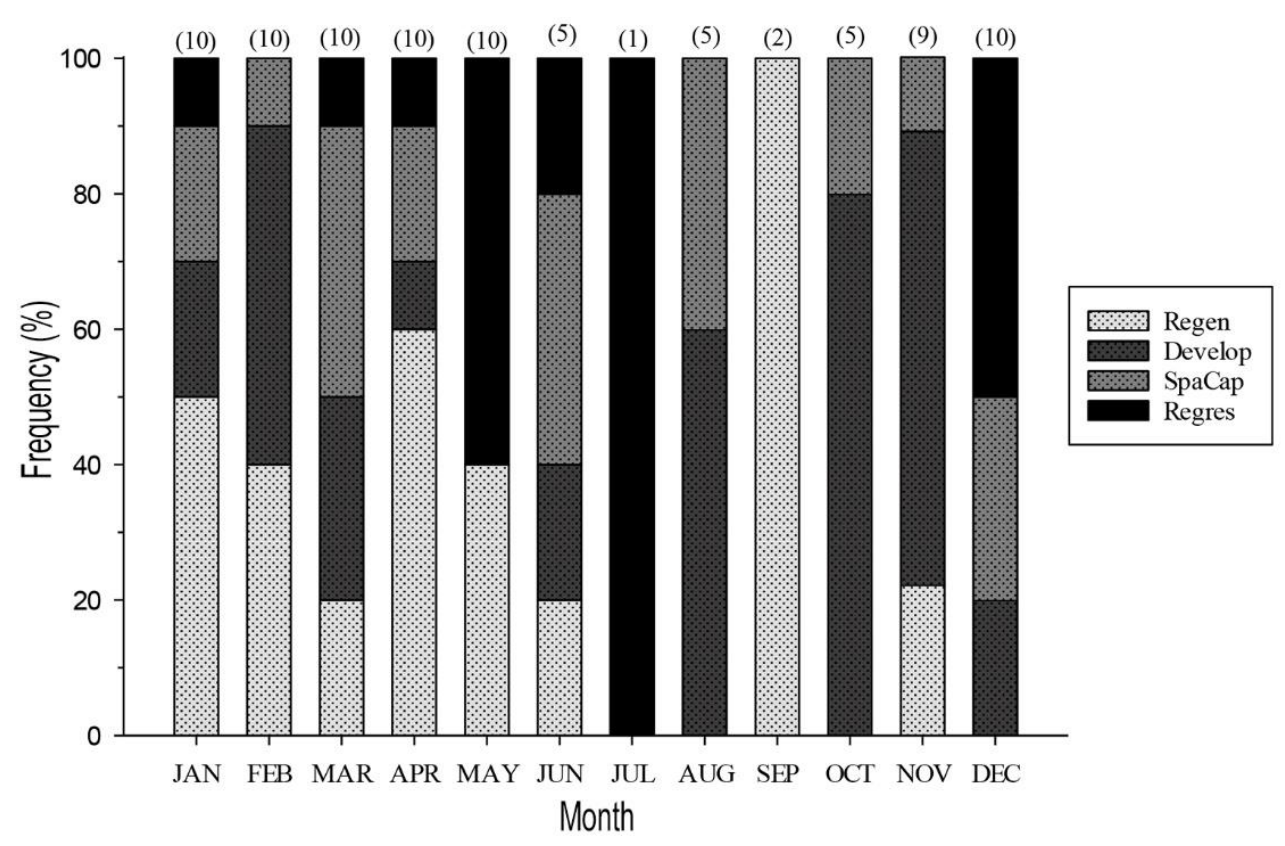

Figure 2. Monthly frequency distribution of the different reproductive phases from Aplodinotus grunniens females captured in the middle Usumacinta River. Regen: regenerating, Develop: developing; SpaCap: spawning capable, Regres: regressing. The number of females sampled per month is indicated in parenthesis.

ation of oil droplets and yolk globules through the ooplasm, causing a significant increase in oocyte size (Figs. 4e-g). From all the oocyte steps observed, the early secondary growth (SGe) was the most frequent step $(27.7 \%)$, with oocytes ranging from $200-500 \mu \mathrm{m}$ (Figs. 4a-b).

\section{Spawning capable}

This phase occurred more frequently in March, June and August, (Fig. 2), corresponding to females between 28.15 and $39.34 \mathrm{~cm} \mathrm{TL}(33.09 \pm 3.56 \mathrm{~cm})$, with a total weight ranging from 231.10 to $698.56 \mathrm{~g}(437.44 \pm$ $163.44 \mathrm{~g}$ ). Females at this stage had an average GSI of $3.77 \pm 1.48$. Ovaries were homogenous in their shape; they occupied most of the coelomic cavity and showed lesser vascularization when compared with the previous phase (Fig. 5a). At a gross level, oocytes had spherical morphology and coloration ranging from yellow to orange. Ovary length in this phase varied between 45.61 and $111.29 \mathrm{~mm}(80.73 \pm 15.30 \mathrm{~mm})$, weighing between 8.42 and $41.30 \mathrm{~g}(18.19 \pm 10.02 \mathrm{~g})$ and with an average gonad volume of 5,788.17 \pm $4,510.08 \mathrm{~mm}^{3}$. In this phase, most oocytes corresponded to the oocyte maturation stage (Figs. 5b-g); however, a few primary and secondary growth oocytes were also observed, of which some become atretic (Figs. 5b-c). The oocyte maturation stage appeared represented by the following steps: eccentric germinal vesicle (OMegv), germinal vesicle migration (OMgvm) and germinal vesicle breakdown (OMgvb) (Figs. 5e-g). The OMegv step was the most frequent (45\%). These oocytes had a maximum diameter of $620 \mu \mathrm{m}$, and their cytoplasm appeared filled with merging oil droplets and yolk globules (Fig. 5e). In the germinal vesicle breakdown step (OMgvb) oil droplets merged into a single oil globule and the cytoplasm became filled with a continuous yolk mass, in such a way that the germinal vesicle was no longer visible (Fig. $5 \mathrm{~g}$ ).

\section{Regressing}

Ovaries, in this phase, presented their highest frequency in May and July (Fig. 2). Females had between 27.03 and $41.23 \mathrm{~cm}$ TL $(33.40 \pm 4.55 \mathrm{~cm})$ and a total weight ranging from 173.41 to $717.52 \mathrm{~g}(399.64 \pm 177.67 \mathrm{~g})$. Females had an average GSI of $0.70 \pm 0.63$. Generally, these ovaries were flaccid, with hemorrhagic appearance towards the caudal region, and occupying $1 / 3$ of the coelomic cavity (Fig. 6a). Ovaries ranged from 40.12 to $77.31 \mathrm{~mm}(63.19 \pm 11.03 \mathrm{~mm})$, with a weight between 1.01 and $10.42 \mathrm{~g}(3.52 \pm 2.60 \mathrm{~g})$, and an average volume of $814.53 \pm 490.91 \mathrm{~mm}^{3}$. At the histological level, the Regressing phase was characterized by presenting a thickened ovarian wall, numerous blood vessels, muscle bundles (Figs. 6b,e,f), scattered oogonia and primary growth oocytes in one nucleolus (PGon), multiple nucleoli (PGmn), perinucleolar (PGpn), cortical alveoli (PGca) and oil droplet (PGod) steps, which appeared separated by abundant 


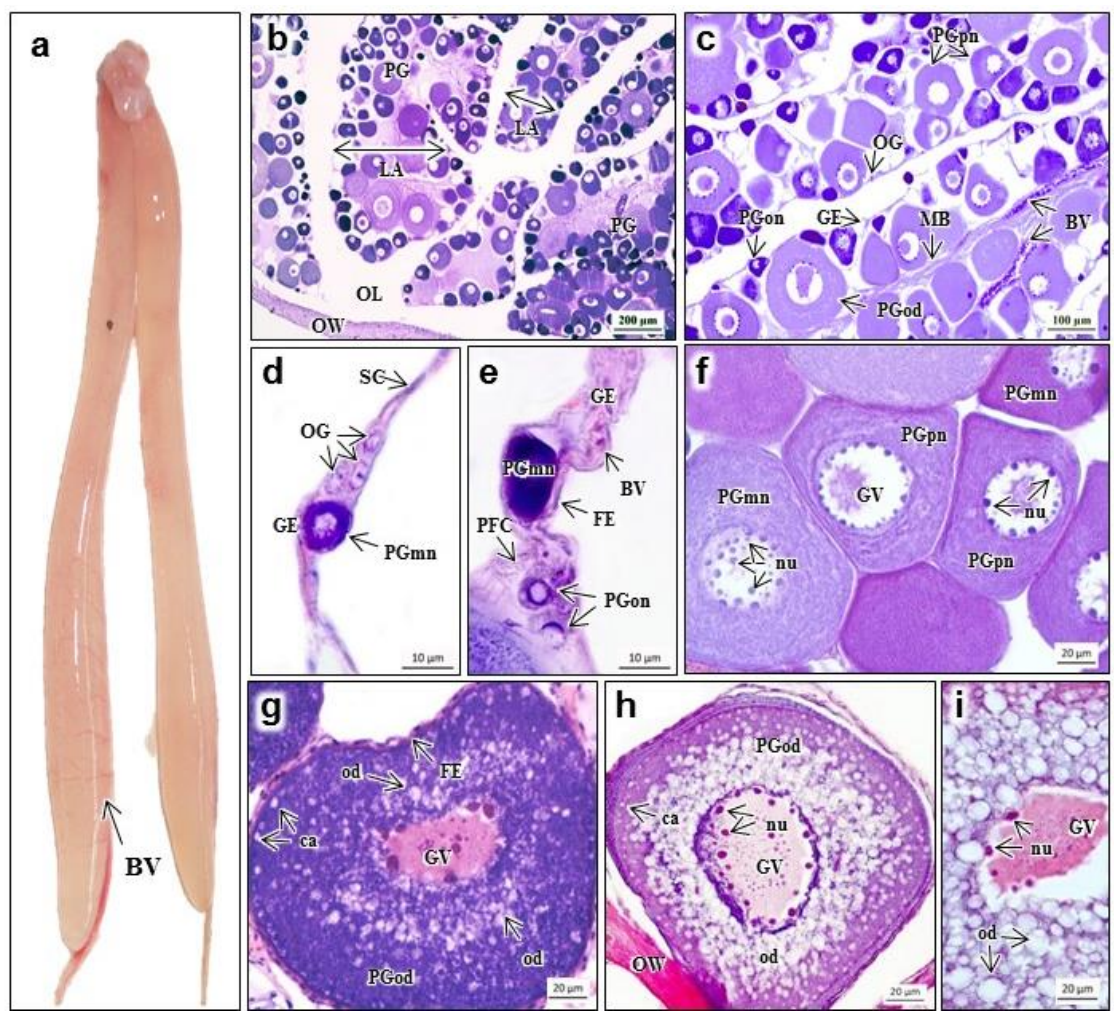

Figure 3. Aplodinotus grunniens ovaries during the regenerating phase. a) Ovaries in this phase are thin and peach colored. Blood vessels (BV) are barely recognizable with the naked eye; b) these ovaries have notorious ovigerous lamellae (LA) containing a large number of oocytes in various steps of the primary growth stage (PG); c) ovigerous lamellae are bordered by germinal epithelium (GE) containing oogonia (OG) and PG oocytes at the one nucleolus step (PGon). Lamella consist of ovarian stroma containing muscle bundles (MB) and more advanced PG oocytes, such as the perinucleolar (PGpn) and oil droplet steps (PGod); d-e) the GE is integrated by somatic (SC, epithelial cells; PFC, pre-follicular cells) and germ cells (OG, oogonia; PGon, oocytes in the one nucleolus step); it is also the place where oogenesis starts, f) a group of PG oocytes in the multiple nucleoli step (PGmn) with irregularly distributed nucleoli (nu) and PGpn with nucleoli attached to the nuclear envelope. In the perinucleolar step (PGpn) nucleoli (nu) become associated to the nuclear envelope; g-h) PG oocytes in the oil droplet step containing increasing amounts of oil droplets (od) as oogenesis proceeds. The perinucleolar condition is maintained and the ooplasm turns eosinophilic; i) amplification of the ooplasm of a PGod oocyte showing plenty oil droplets (od) next to the germinal vesicle $(\mathrm{GV})$. Ovarian wall $(\mathrm{OW})$, ovarian lumen (OL), blood vessel (BV), follicular epithelium $(\mathrm{FE})$, cortical alveoli (ca), germinal vesicle (GV), nucleoli (nu). Hematoxylin and eosin stained.

interstitial tissue (Figs. 6e-g). No secondary growth oocytes were observed during this phase. Also, degenerating post-ovulatory follicles were observed, indicating that spawning has occurred early. Many mature, secondary and primary growth oocytes were observed undergoing atresia (Figs. 6c,d,g), giving the ovarian stroma a liquefy appearance.

\section{Monthly variation in oocyte diameter, GSI, HSI and GV}

The distribution of oocyte diameter frequencies across different maturity phases throughout the year showed a large data dispersion with different modal groups (Fig. 7 ), indicating that $A$. grunniens is a partial spawner. The occurrence of spawning capable females throughout the year supports this statement (Fig. 2), which presented secondary growth and mature oocytes with diameters ranging from 548.1 to $838.9 \mu \mathrm{m}$ (Fig. 7).

The GSI presented peaks in June, August and October (Fig. 8), alternating with drops in May, July and September, though it is worth to mention that in July and September only one and two fish were captured, respectively. The HSI presented a similar fluctuation pattern than GSI, peaking in February, June, August and October, with alternating drops in May, July and September (Fig. 8). Increases in GSI and HSI during these months coincided with the high frequency of developing and spawning capable ovaries, as revealed by histology (Fig. 2). On the other hand, drops in the GSI and HSI coincided with the high frequency of regenerating and regressing ovaries in May, July and September (Fig. 2). The occurrence of postovulatory 


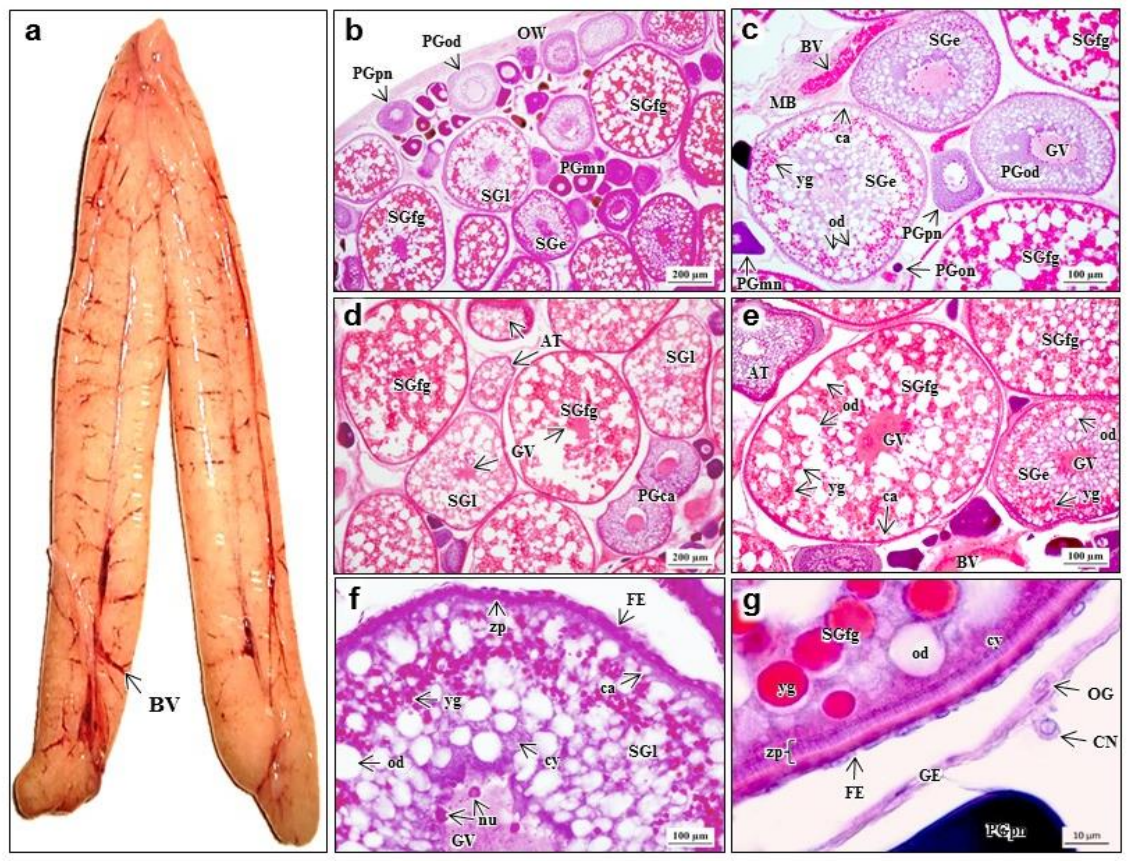

Figure 4. Aplodinotus grunniens ovaries during the developing phase. a) At this phase, gonads show gold-sand color and notorious blood vessels (BV); b) cross-section of an ovary showing oocytes in different stages of development. There is a predominance of secondary growth oocytes (SG) in early (SGe), late (SGl) and full grown (SGfg) steps. The co-ocurrence of developing primary growth oocytes such as multiple nucleoli (PGmn), perinucleolar (PGpn) and oil droplet (PGod,) is indicative of asynchronous ovarian development; c) magnified view of PG (PGon: one nucleolus, PGpn: perinucleolar and PGod: oil droplet step) and SG (SGe, Early and SGfg, full grown) oocytes; d-e) SG oocytes (SGe, SGl and SGfg) gradually increase their sizes due to the massive accumulation of yolk globules (yg) and oil droplets (od), which start merging in larger inclusions. Regardless of this, the germinal vesicle $(\mathrm{GV})$ remains central. Some atretic follicles (AT) are observed; f) during the Secondary growth late step (SGl), oocyte cytoplasm (cy) is filled with yolk globules (yg) and oil droplets (od); g) detail of the peripheral ooplasm of a Secondary growth full grown oocyte (SGfg) showing oil droplets (od) and yolk globules (yg). There is a strip of cytoplasm (cy) immediately over the zona pellucida (zp). The oocyte is surrounded by a flat follicular epithelium (FE). An oogonium (OG) and a chromatin nucleolus oocyte (CN) are observed in the germinal epithelium (GE). Ovarian wall (OW), blood vessel (BV), germinal vesicle (GV), nucleoli (nu), zona pellucida (zp), follicular epithelium (FE), cortical alveoli (ca), primary growth perinucleolar oocyte (PGpn). Hematoxylin and eosin stained.

follicles in regressing ovaries demonstrated that spawning occurred in May, July and September. All these data, taken together, suggest that A. grunniens inhabiting the Usumacinta River reproduces yearround, with spawning events occurring preferably during the second semester of the year, from June to November.

\section{Environmental parameters}

Water temperature ranged from $24^{\circ} \mathrm{C}$ in December to $29^{\circ} \mathrm{C}$ in May. Rainfall ranged from $1.5 \mathrm{~mm}$ in March to $19 \mathrm{~mm}$ in November. The level of the Usumacinta River reached its lowest value in April, with 12 m.a.s.l, getting the largest depth $(18.17 \mathrm{~m})$ in October (Table 1). Rainfall was high along the second semester of the year initiating in June with $10.7 \mathrm{~mm}$ and ending in December with $14 \mathrm{~mm}$.
Table 1. Average monthly values of river level, rainfall and water temperature registered in the study site. Data for river level and rainfall were obtained from the CONAGUA meteorological station number 30019; m.a.s.l: meters above sea level.

\begin{tabular}{lccc}
\hline Month & $\begin{array}{c}\text { River level } \\
(\mathrm{masl})\end{array}$ & $\begin{array}{c}\text { Rainfall } \\
(\mathrm{mm})\end{array}$ & $\begin{array}{c}\text { Water } \\
\text { temperature }\left({ }^{\circ} \mathrm{C}\right)\end{array}$ \\
\hline January & 15.12 & 5.3 & 25 \\
February & 13.75 & 3.6 & 26 \\
March & 12.43 & 1.5 & 24 \\
April & 12.00 & 4 & 27 \\
May & 12.77 & 5.9 & 29 \\
June & 17.31 & 10.7 & 27 \\
July & 16.90 & 5.7 & 27 \\
August & 16.69 & 8.5 & 27 \\
September & 18.01 & 11.2 & 26 \\
October & 18.17 & 15 & 25 \\
November & 14.73 & 19 & 26 \\
December & 13.53 & 14 & 24 \\
\hline
\end{tabular}




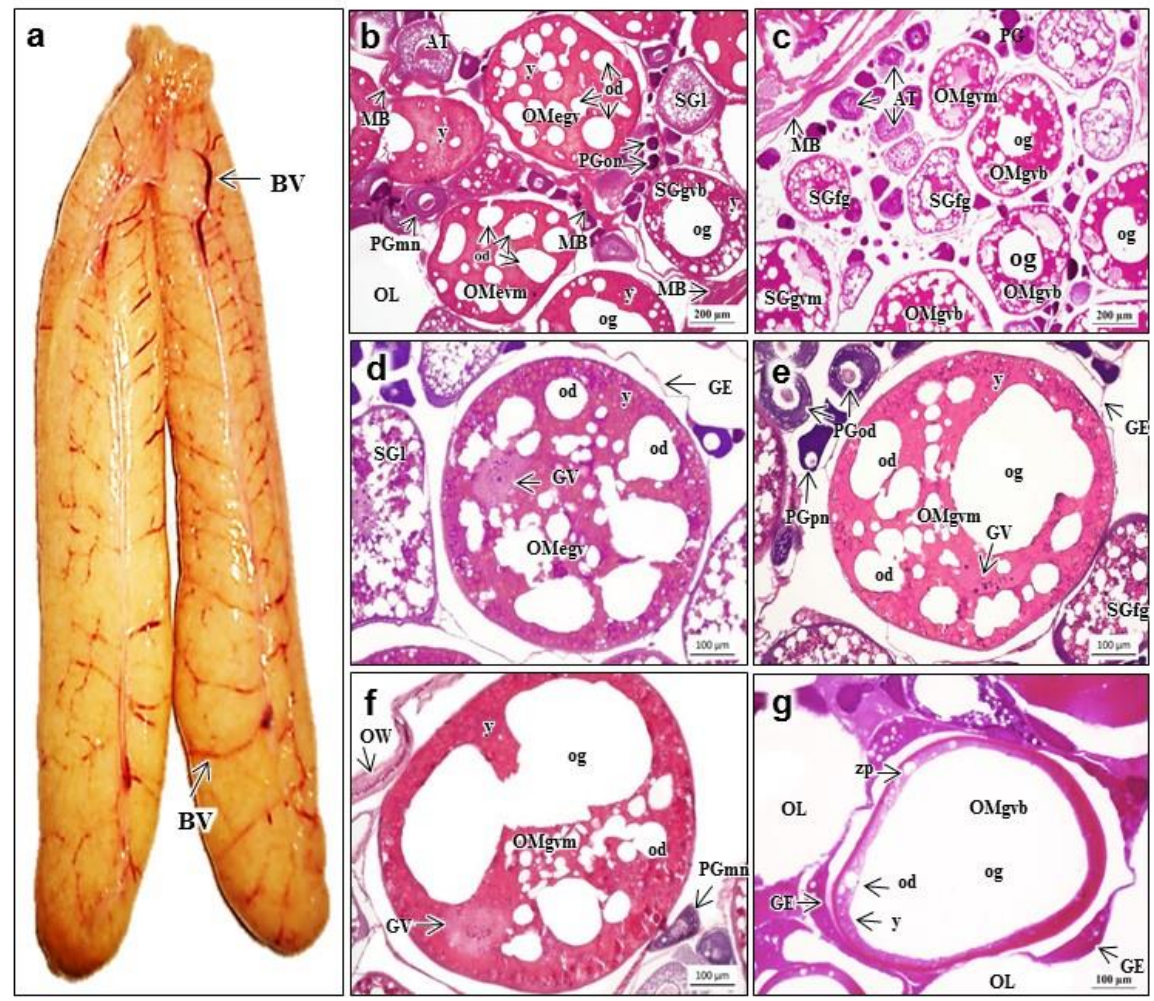

Figure 5. Aplodinotus grunniens ovaries during the spawning capable phase. a) Ovaries show a sweet-corn color and large blood vessels (BV). Oocytes are visible with the naked eye; b) cross section of an ovigerous lamellae showing oocytes in different stages of development: primary growth oocytes in one nucleoli (PGon) and multiple nucleoli (PGmn) steps as well as secondary growth oocytes in late (SGl) steps; $\mathrm{c}$ ) in spawning capable ovaries there is a predominance of mature oocytes (Oocyte maturation stage), with the eccentric germinal vesicle (OMegv) and germinal vesicle breakdown (OMgvb) being the most common steps; d) an oocyte in the OMegv with its characteristic eccentric germinal vesicle (GV). Oil droplets (od) have fused in several oil globules of middle size; e) a germinal vesicle migration (OMgvm) oocyte showing a flattened germinal vesicle $(\mathrm{GV})$ being pushed towards the animal pole by a coalescent oil globule $(\mathrm{og})$. The oocyte is surrounded by primary (PGod, oil droplet and PGpn perinucleolar steps) and secondary growth (SGfg, full grown) oocytes; f) in OMgvm oil droplets (od) continue merging in a huge oil globule. In this oocyte the germinal vesicle (GV) has reached the animal pole, where the rupture of the germinal vesicle will subsequently take place; g) an oocyte in the final step of maturation, the germinal vesicle breakdown $(\mathrm{OMgvb})$, where the $\mathrm{GV}$ is no longer recognizable. The fusion of yolk globules and oil droplets is completed. PGmn, primary growth multiple nucleoli oocyte; SGfg, secondary growth full grown oocyte; MB, muscle bundle; AT, follicular atresia; OW, ovarian wall; OL, ovarian lumen, GE, germinal epithelium; zp, zona pellucida. Hematoxylin and eosin stained.

\section{DISCUSSION}

The results indicate that Aplodinotus grunniens is an iteroparous species that reproduce year-round, with peaks of gametogenesis occurring in January, June and October, and with spawning occurring in May, July, September and November. The histological analysis revealed the co-occurrence of oocytes in various developmental stages throughout the year, ranging from primary growth to oocyte maturation stages, consistent with the definition of asynchronous ovarian development (Wallace \& Selman, 1981). It means that females can shed oocyte batches at different moments of the year. Asynchronous development of oocytes is associated with an indefinite fertility strategy, where the potential annual fertility is not fixed before spawning, but instead, primary growth oocytes are continuously recruited for maturation in order to be released along the reproductive season (Murua \& Saborido-Rey, 2003). In addition to those features mentioned above, the absence of spacing (hiatus) among oocyte diameter frequencies separating mature from primary growth oocyte stocks, clearly shows that the production of new mature oocytes is continuous. The occurrence of multiple oocyte stages has also been reported in the same species inhabiting in USA and 


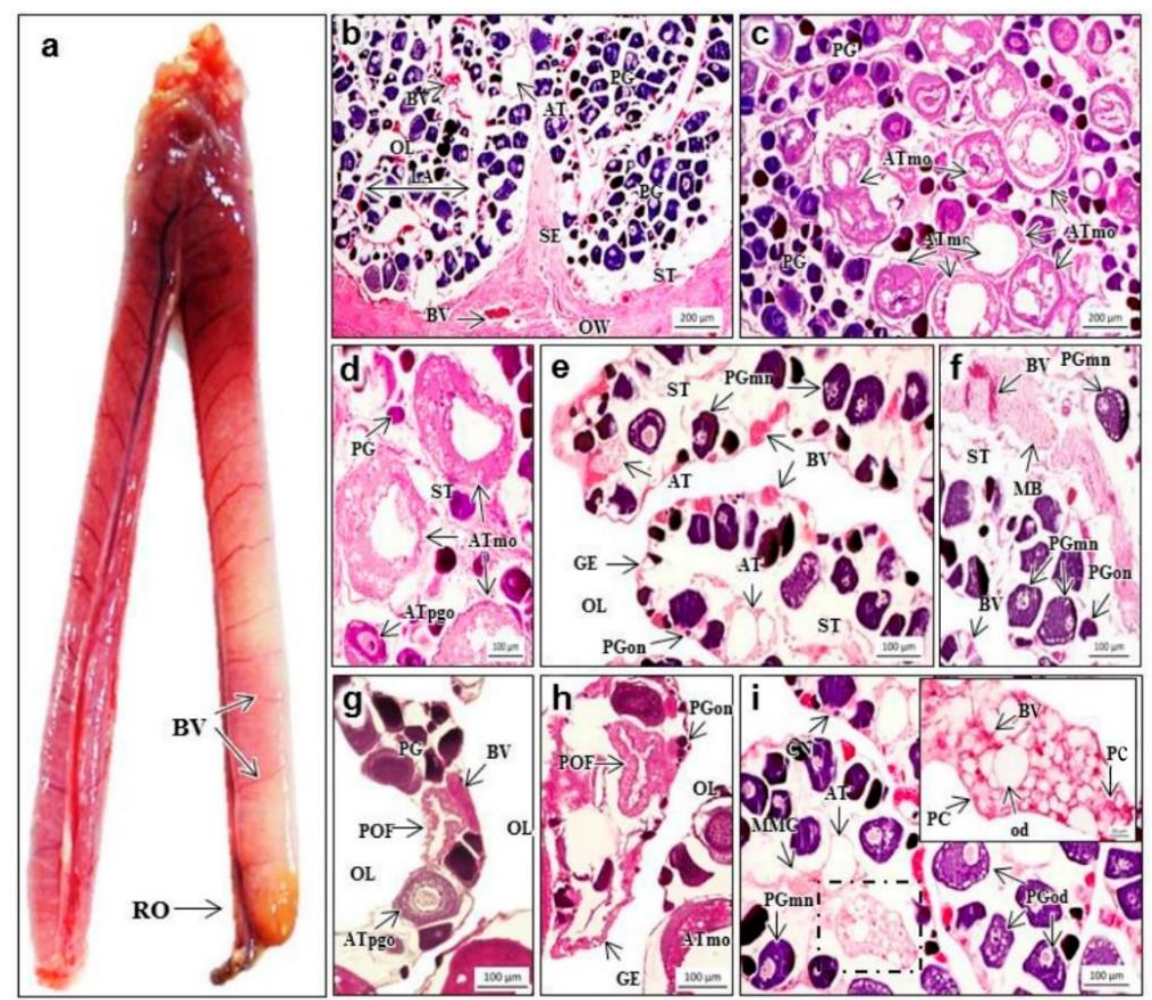

Figure 6. Aplodinotus grunniens ovaries during the regressing phase. a) Macroscopic appearance of an ovary in the regressing phase. The color ranged between pink and plumb. In some cases, residual mature oocytes (RO) were seen; b) histologically, the ovaries show a thickened ovarian wall (OW) with large septa (SE) protruding into the ovarian stroma (ST); c) many atretic follicles in several stages of degeneration occur during this phase, mainly non-ovulated mature oocytes (ATmo) that are resorbed by atresia. Primary growth oocytes start to develop at the same time, chiefly PG one nucleolus (PGon) and multiple nucleoli (PGmu) oocytes; d) amplification of some atretic mature oocytes (ATmo). The ooplasm is liquefied and oocyte morphology turns irregular. Atretic primary growth oocytes (ATpgo) were observed as well; e) regressing ovaries were characterized by abundance of small blood vessels (BV), mainly in the germinal epithelium (GE), which contained primary growth one nucleolus (PGon) and multiple nucleoli (PGmn) oocytes. Atretic follicles (AT) are scattered in the ovarian stroma (ST), surrounded by developing oocytes in primary growth (PG); f) these ovaries presented spaced oocytes (PGon and PGmn) and muscle bundles (MB) in the ovarian stroma (ST); g-h) ovigerous laemella displaying postovulatory follicles (POF) next to the ovarian lumen (OL); i) follicular atresia (AT) was the most common event in regressing ovaries. The inset is an amplification of the dotted area and depicts an advanced atretic mature oocyte being resorbed by phagocytic cells (PC) and blood vessels (BV). Melanomacrophague centers (MMC) seems to be involved in this process as well. Ovarian lumen (OL), ovigerous lamellae (LA), primary growth oocytes (PG), blood vessel (BV), follicular atresia (FA), ovarian stroma (ST), chromatin nucleolus oocyte $(\mathrm{CN})$, primary growth oil droplet oocyte (PGod), oil droplet (od). Hematoxylin and eosin stained.

Canada (Daiber, 1953; Palmer et al., 1995). As a matter of fact, the majority of species belonging to the Sciaenidae family that occur in the tropical and subtropical regions such as the white seabass Atractoscion nobiles, the corvina drum Cilus gilberti, the seatrout Cynoscion nebulosus and the brown meagre Sciaena umbra, all are considered asynchronous and iteroparous (Brown-Peterson et al., 1988; Cárdenas, 2012). However, there are several saltwater species from the same family that use synchronous spawning as reproductive strategy, such as the red drum Sciaenops ocellatus, the croaker Argyrosomus regius and the Shi drum Umbrina cirrosa (Wilson \& Nieland, 1994; Mylonas et al., 2004; Shabana et al., 2012; Gil et al., 2013). The GSI and HSIs showed alternating peaks and drops caused by the presence of gametogenic and spawned females, respectively, pointing out that $A$. grunniens reproduce continuously, especially during the second semester of the year (June-November). These results, taken together with the occurrence of asynchronous ovarian development, indefinite fertility, and partial spawning, indicate that A. grunniens from the Usumacinta River reproduce year-round. Probably due to the existence of favorable environmental condi- 

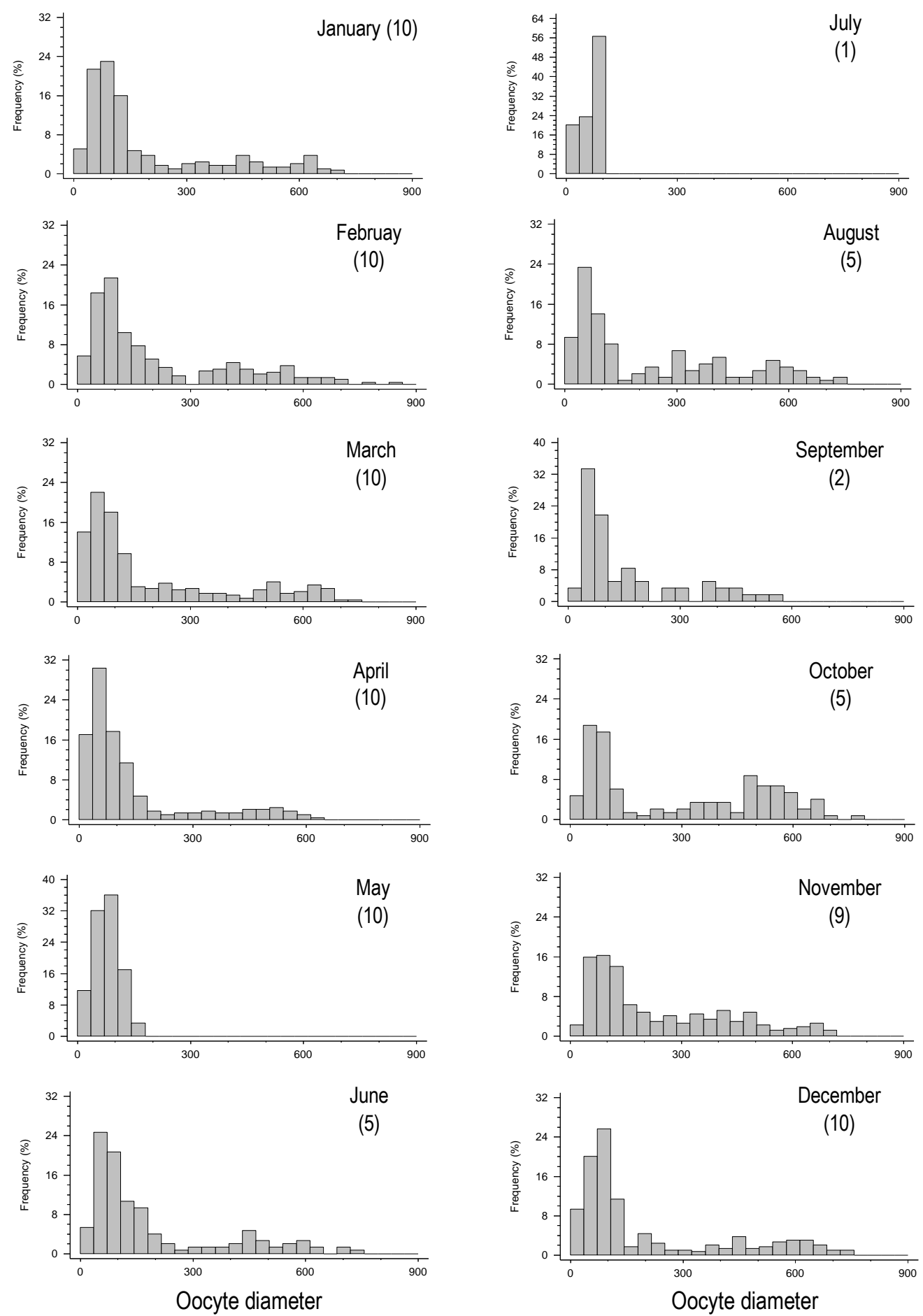

Figure 7. Monthly size frequency distributions of the oocyte diameters as measured at the microscope $(\mathrm{n}=30$ oocytes from each female). The number of females sampled per month is indicated in parenthesis.

tions for the development and survival of offspring, especially in the rainfall-flooding season, when heavy rainfalls cause the rising of the river and the flooding of riverside areas.
During the reproductive cycle of A. grunniens, four reproductive phases of the female gonad were identified; regenerating, developing, spawning capable and regressing, with almost all the stages of oogenesis co-occurring in the same gonad throughout the year. In 


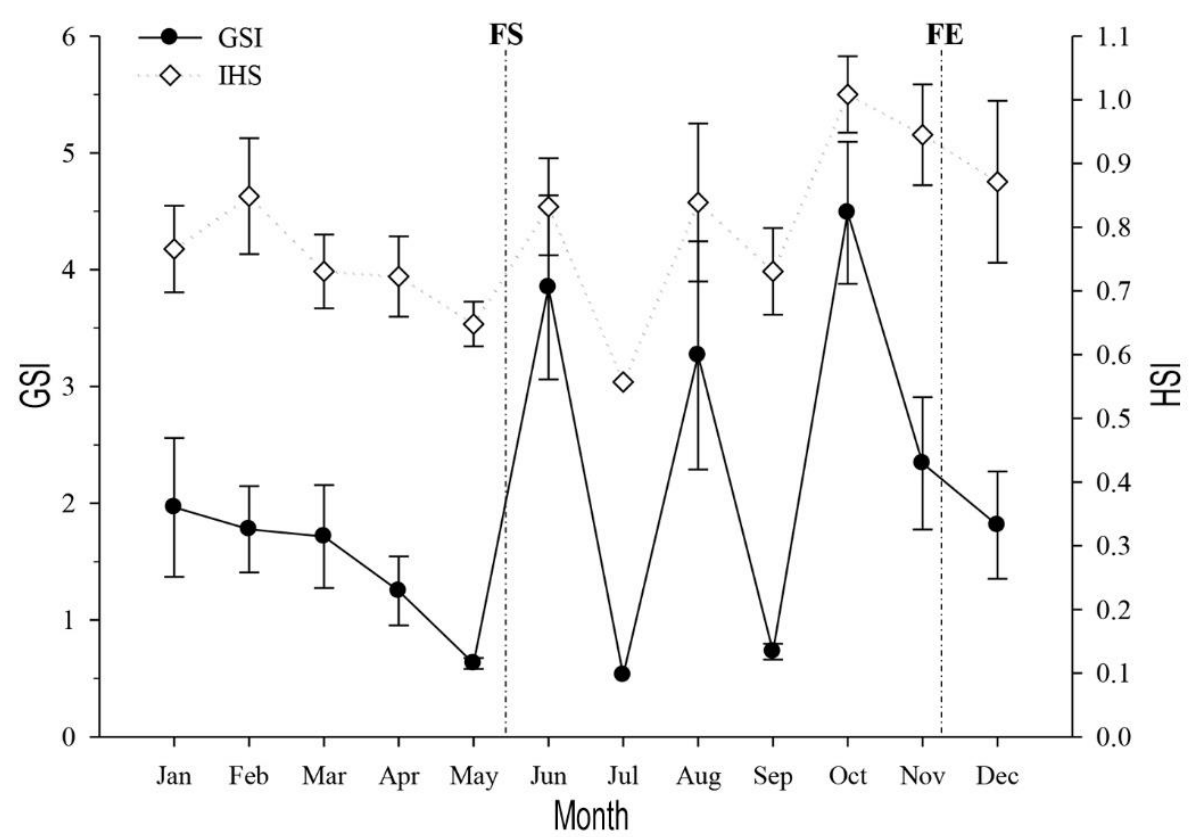

Figure 8. Reproductive indices of Aplodinotus grunniens females and duration of the flooding season. GSI: gonadosomatic index, HIS: hepatosomatic index. Dotted lines indicate the beginning (FS) and the end (FE) of the flooding season.

in general, in terms of gonadal stages, for the same species but inhabiting the Lake Erie, between USA and Canada, the stages of oogenesis described in the present study were similar to those described for other species of the same family. Such as Sciaenops ocellatus, Sciaena umbra, the whitemouth croaker Micropogonias furnieri, roncador Umbrina robinsoni, yellowfin croaker Umbrina roncador, silver croaker Bairdiella chrysoura, croaker Argyrosomus regius, yellow croaker Larimichthys polyactis, southern kingcroaker Menticirrhus americanos and South American silver croaker Plagioscion squamosissimus (Valdebenito et al., 1995; Félix et al., 2009; Grau et al., 2009; Miller et al., 2009; Hutching \& Griffiths, 2010; Lim et al., 2010; Grier, 2012; Gil et al., 2013).

The occurrence of post-ovulatory follicles (POFs) in fish is the most reliable evidence for determining spawning (Ganias, 2012). Daiber (1953) and Palmer et al. (1995) confirmed ovulation in A. grunniens based on the presence of POFs as indicators of spawning. In this study, POFs were present year-round and coincided with drops in the GSI, which is explained by the releasing of egg masses from the ovaries. Postovulatory follicles were mainly identified in regressing ovaries (usually termed as post-spawning ovaries in the fisheries literature) after cessation of spawning. Besides using POFs, we used other histological criteria as indicators of spawning, such as the presence of atretic follicles, a thickened ovarian wall and broad dispersion of primary and secondary growth oocytes (Brown-
Peterson et al., 2011). Although POFs were present in all the regressing ovaries. Their number was much smaller in comparison with the number of mature oocytes observed in spawning capable ovaries. This small quantity of POFs in regressing ovaries might be due to the fast degeneration of these structures, since according to the literature POFs in the ovary of sciaenids last around $24 \mathrm{~h}$, after which they degenerate rapidly (Saborido-Rey, 2008; Hutchings \& Griffiths, 2010). Further studies must be focused on determining the timing and sequence of morphological events involved in the degeneration of POFs in A. grunniens.

The nutritional condition of the females determines the spawning season of a species, so they have to accumulate enough energy reserves in order to support gametogenesis and carry out a successful spawning (Saborido-Rey, 2008). In this study, data from gonadal histology, GSI and HSIs strongly suggest that $A$. grunniens from the Usumacinta River reproduce yearround, pointing out favorable conditions for growth and reproduction throughout the year. However, our results also show an increased channeling of energy for reproduction towards summer-autumn that might be related to an increase in food availability for offspring during the rainfall-flooding season (June-November), when the increase in river flow causes the flooding of riverside areas. From these observations, it is clear that the reproductive strategy of $A$. grunniens from the Usumacinta River differs with $A$. grunniens specimens from northern populations, such as those from the Red 
Lakes, USA (Palmer et al., 1995) and several other sciaenids species that reproduce either in spring or summer, such as the brown meager Sciaena umbra, Bairdiella chrysoura, Larimichthys polyactis, Menticirrhus americanus, Sciaena umbra and Umbrina roncador (Ferreira et al., 2011; Grammer et al., 2009; Grau et al., 2009; Miller et al., 2009; Lim et al., 2010).

We observed an association between environmental parameters, increases in the GSI, frequency of spawning capable ovaries (reproductively active females) and the frequency of mature oocytes larger than $600 \mu \mathrm{m}$. The moment and duration of spawning events in sciaenid fishes have been linked to water temperature, beginning with the rise of water temperature and ending when it drops (Hutchings \& Griffiths, 2010). A. grunniens adapts to highly diverse environmental conditions as shown by its wide geographical distribution. The reported temperature in spawning grounds ranges from temperate $\left(18.9-24.5^{\circ} \mathrm{C}\right)$ in the Lewis and Clark Lake in USA (Wismer \& Christie, 1987$)$ to $\operatorname{mid}\left(24-27^{\circ} \mathrm{C}\right)$ in the Missouri River in the US (Braaten \& Guy, 2004) to tropical $\left(26-29^{\circ} \mathrm{C}\right)$ in this study. According to Valdebenito et al. (1995), the reproductive cycle of fishes is mainly regulated by environmental factors, predominantly temperature and photoperiod, which are important for maturity and spawning. Additionally, in river ecosystems different annual nutrient cycles coincide with the rise of river level and flooding, creating conditions that are favorable for the survival and growth of larvae and juveniles, as described for Sciaena umbra and Umbrina robinsoni (Grau et al., 2009). The rainy season is an environmental factor that influences the reproductive cycle of a species, because increased flows and flooded areas may constitute sheltering and nursing places for developing larvae and juveniles (Peña-Mendoza et al., 2011).

\section{CONCLUSIONS}

The contribution of this research on the reproductive cycle of Aplodinotus grunniens females in the Usumacinta River must be considered for the development of a management plan in the river and its influences zones, with an emphasis on the highest reproductive activity period, which coincides with the highest fishing activity in the zone. The freshwater drum A. grunniens has a high biological, ecological and nutritional value in the region and that is why management measures should be implemented to guarantee the permanency of this valuable resource. Moreover, the understanding of the reproductive dynamics of this species will allow developing strategies for its captive management for aquaculture purposes.

\section{ACKNOWLEDGMENTS}

This paper resulted from joint efforts among the Universidad Juárez Autónoma de Tabasco, the Programa de Mejoramiento del Profesorado (PROMEP) and Fondos Mixtos CONACYT-Government of Tabasco. The authors thank Moisés González-Valencia for his technical assistance in the preparation of histological material.

\section{REFERENCES}

Aguilar, M.M., Coutiño, B.B. \& Salinas, P.R. 2013. Técnicas histológicas y citoquímicas. Las Prensas de Ciencias, México, D.F.

Álvarez-Merino, A.M., Barba-Macías, E., Benítez-Abud, J.A. \& Cabrera-Ballona, A. 2014. El río Usumacinta y su zona de inundación como un solo ecosistema: caso de estudio Ejido Tres Brazos, Tabasco. In: ChanQuijano, J.G., Espinoza-Tenorio, A. \& López-Jiménez, L.N. (Eds.). Manejo sostenible de los recursos naturales: conocimiento y afectaciones. Ediciones Plan 21, Buenos Aires.

Braaten, P.J. \& Guy, C.S. 2004. First-year growth, condition, and size-selective winter mortality of freshwater drum in the lower Missouri River. Transactions of the American Fisheries Society, 133(2): 385-398.

Brown-Peterson, N., Thomas, P. \& Arnolos, C.R. 1988. Reproductive biology of the spotted seatrout, Cynoscion nebulosus, in south Texas. Fishery Bulletin, 86(2): 373-388.

Brown-Peterson, N., Wyansky, D.M., Saborido-Rey, F., Macewickz, B.J. \& Lowerre-Barbieri, S.K. 2011. A standardized terminology for describing reproductive development in fishes. Marine and Coastal Fisheries, 3: 52-70.

Cabrera, J. \& Cuc, P. 2002. Diagnóstico socioambiental de la cuenca del Río Usumacinta. Universidad de Costa Rica, Costa Rica, 41 pp.

Cárdenas, S. 2012. Biología y acuicultura de corvinas en el mundo. Revista AquaTIC, 37: 1-13.

Chao, N.L. 2002. Sciaenidae, croakers (drums). In: Carpenter, K.E. (Ed.). The living marine resources of the western central Atlantic. Volume 3. Bony fishes part 2 (Opistognathidae to Molidae), sea turtles and marine mammals. Food and Agriculture Organization of the United Nations, Rome, pp. 1583-1653.

Chávez, L.M.O., Matthews, A.E. \& Pérez, M.H.V. 1989. Biología de los peces del Río San Pedro en vista de determinar su potencial para la piscicultura. Ediciones INIREB/FUCID, Xalapa.

Daiber, F.C. 1952. The food and feeding relationships of the freshwater drum, Aplodinotus grunniens Rafines- 
que in western Lake Erie. The Ohio Journal of Science, 52(1): 35-46.

Daiber, F.C. 1953. Notes on the spawning population of the freshwater drum (Aplodinotus grunniens Rafinesque) in western Lake Erie. The American Midland Naturalist, 50(1): 159-171.

Davis-Foust, S.L., Bruch, R.M., Campana, S.E., Olynyk, R.P. \& Janssen, J. 2009. Age validation of freshwater drum using bomb radiocarbon. Transactions of the American Fisheries Society, 138(2): 385-396.

Félix, R.T.D.S., Severi, W., Santos, A.J.G., EL-Deir, A.C.A., Soares, M.G. \& Evêncio-Neto, J. 2009. Ovarian development of Plagioscion squamosissimus (Heckel, 1840) (Actinopterygii, Perciformes), from the Pedra reservoir, Contas River, Bahia. Biota Neotropica, 9(3): 131-136.

Ferreira, C.H., Abilhoa, V., Oliveira, F.M., Maia, C.M.F. \& Hostim-Silva, M. 2011. Estrutura populacional e biología reprodutiva de Menticirrhus americanus (Linnaeus, 1758) (Teleostei, Sciaenidae) na baía de Ubatuba-Enseada, Santa Catarina, Brasil. Biotemas, 24: 47-59.

Ganias, K. 2012. Thirty years of using the postovulatory follicles method: overview, problems, and alternatives. Fisheries Research, 117: 63-74.

Gil, M.M., Grau, A., Basilone, G., Ferreri, R. \& Palmer, M. 2013. Reproductive strategy and fecundity of meagre Argyrosomus regius Asso, 1801 (Pisces: Sciaenidae): implications for restocking programs. Scientia Marina, 77(1): 105-118.

Grammer, G.L., Brown-Peterson, N.J., Peterson, M.S. \& Comyns, B.H. 2009. Life history of silver perch Bairdiella chrysoura (Lacepède 1803) in north-central Gulf of Mexico estuaries. Gulf of Mexico Science, 27(1): 62-73.

Grau, A., Linde, M. \& Grau, A.M. 2009. Reproductive biology of the vulnerable species Sciaena umbra Linnaeus, 1758 (Pisces: Sciaenidae). Scientia Marina, 73(1): 67-81.

Grier, H.J. 2012. Development of the follicle complex and oocyte staging in red drum, Sciaenops ocellatus Linnaeus, 1776 (Perciformes, Sciaenidae). Journal of Morphology, 273: 801-829.

Grier, H.J., Uribe-Aranzabal, M.C. \& Patiño, R. 2009. The ovary, folliculogenesis, and oogenesis in teleosts. In: Jamieson, B.G.M. (Ed.). Reproductive biology and phylogeny of fishes (agnathans and bony fishes). Science Publishers, New Hampshire, pp. 25-84.

Hernández-Gómez, R.E., Perera-García, M.A., Valenzuela, C.I., Duran, M.T. \& Mendoza-Carranza, M. 2013. Embryonic development of Aplodinotus grunniens (Perciforme: Sciaenidae) in Tenosique, Tabasco,
Mexico. International Journal of Morphology, 31(2): 633-639.

Humason, G.L. 1979. Animal tissue techniques. W.H. Freeman and Company, San Francisco.

Hutchings, K. \& Griffiths, M.H. 2010. Life-history strategies of Umbrina robinsoni (Sciaenidae) in warmtemperate and subtropical South African marine reserves. African Journal of Marine Science, 32(1): 37-53.

Jacquemin, S.J. \& Pyron, M. 2013. Effects of allometry, sex, and river location on morphological variation of freshwater drum Aplodinotus grunniens in the Wabash River, USA. Copeia, 4: 740-749.

Jacquemin, S.J., Pyron, M., Allen, M. \& Etchison, L. 2014. Wabash River freshwater drum Aplodinotus grunniens diet: effects of body size, sex, and river gradient. Journal of Fish and Wildlife Management, 5(1): 133-140.

Lim, H.K., Le, M.H., An, C.M., Kim, S.Y., Park, M.S. \& Chang, Y.J. 2010. Reproductive cycle of yellow croaker Larimichthys polyactis in southern waters of Korea. Fisheries Science, 76(6): 971-980.

Méndez-Marin, O., Hernández-Franyutti, A.A., ÁlvarezGonzález, C.A., Contreras-Sánchez, W.M. \& UribeAranzábal, M.C. 2012. Histología del ciclo reproductor de hembras del pejelagarto Atractosteus tropicus (Lepisosteiformes: Lepisosteidae) en Tabasco, México. Revista de Biología Tropical, 60(4): 1857-1871.

Miller, E.F., Goldberg, S., Nunez, J., Burkes, N. \& Kuratomi, J. 2009. The reproductive biology of two common surf zone associated sciaenids, yellowfin croaker (Umbrina roncador) and spotfin croaker (Roncador stearnsii), from southern California. Bulletin of the Southern California Academy of Sciences, 108(3): 152-159.

Murua, H. \& Saborido-Rey, F. 2003. Female reproductive strategies of marine fish species of the north Atlantic. Journal of Northwest Atlantic Fishery Science, 33: 2331.

Mylonas, C.C., Kyriakou, Y., Sigelaki, I., Georgiou, G., Stephanou, D. \& Divanach, P. 2004. Reproductive biology of the shi drum (Umbrina cirrosa) in captivity and induction of spawning using GnRHa. Israeli Journal of Aquaculture-Bamidgeh, 56(2): 75-92.

Nelson, J.S. 1994. Fishes of the world. Wiley \& Sons, New York.

Palmer, E.E., Sorensen, P.W. \& Adelman, I.R. 1995. A histological study of seasonal ovarian development in freshwater drum in the red Lakes, Minnesota. Journal of Fish Biology, 47(2): 199-210.

Peña-Mendoza, B., Gómez-Márquez, J.L. \& GarcíaAlberto, G. 2011. Ciclo reproductor e histología de las 
gónadas de tilapia Oreochromis niloticus (Perciforme: Cichlidae). Ciencia Pesquera, 19(2): 23-36.

Rodríguez-Gutiérrez, M. 1992. Técnicas de evaluación cuantitativa de la madurez gonádica en peces. AGT México, México D.F.

Rossendllum, M., Pudney, J. \& Gallard, I. 1987. Gonadal morphology enzyme histochemistry and plasma steroid levels during the annual reproductive cycle of male and female brown bullhead catfish, Ictalurus nebulosus Lesueur, Journal of Fish Biology, 31(3): 325-341.

Rypel, A.L. 2007. Sexual dimorphism in growth of freshwater drum. Southeastern Naturalist, 6(2): 333342.

Rypel, A.L., Bayne, D.R. \& Mitchell, J.B. 2006. Growth of freshwater drum from lotic and lentic habitats in Alabama. Transactions of the American Fisheries Society, 135(4): 987-997.

Saborido-Rey, F. 2008. Ecología de la reproducción y potencial reproductivo en las poblaciones de peces marinos. Instituto de Investigaciones Marinas (CSIC), Curso de Doctorado, Universidad de Vigo, Vigo, 71 pp.

Shabana, N.M.A., El Rahman, S.H.A., Al Absawy, M.A. \& Assem, S.S. 2012. Reproductive biology of Argyrosomus regius (Asso, 1801) inhabiting the south eastern Mediterranean Sea, Egypt. The Egyptian Journal of Aquatic Research, 38(2): 147-156.

Received: 14 August 2018; Accepted: 19 April 2019
Sluss, A. \& Harrel S. Animal Diversity. (2006). Aplodinotus grunniens. [http://141.213.176.11/site/ accounts/information/Aplodinotus_grunniens.html]. Reviewed: 15 June 2018.

Valdebenito, I., Peredo, S., González, K. \& Sobarzo, C. 1995. Ciclo reproductivo anual del "Huaiquil o Roncador" (Micropogonias furnieri Desmarest, 1823 Sin. Micropogonias manni Moreno, 1970) (Pisces: Sciaenidae) del Lago Budi. Estudios Oceanológicos, 14: 29-37.

Wallace, R.A. \& Selman, K. 1981. Cellular and dynamic aspects of oocyte growth in teleosts. American Zoologist, 21(2): 325-343.

Wallus, R. \& Simon, T.P. 2006. Reproductive biology and early life history of fishes in the Ohio River drainage, Aphredoderidae through Cottidae, Moronidae, and Sciaenidae. CRC Press, Boca Ratón.

Wilson, C.A. \& Nieland, D.L. 1994. Reproductive biology of red drum, Sciaenops ocellatus from the neritic waters of the northern Gulf of Mexico. Fishery Bulletin, 92(4): 841-850.

Wismer, D.A. \& Chistie, A.E. 1987. Temperature relationships of great lakes fishes. Great Lakes Fishery Commission Special Publication, 87(3): 1-165. 